\title{
Serotonin 1A Receptors Alter Expression of Movement Representations
}

\author{
Kathleen Scullion, ${ }^{1,2 \star}$ Jeffery A. Boychuk, ${ }^{1 \star}$ Glenn R. Yamakawa, ${ }^{1,5}$ Justin T.G. Rodych, ${ }^{1,5}$ Stan T. Nakanishi, ${ }^{3}$ \\ Angela Seto, ${ }^{1,5}$ Victoria M. Smith, ${ }^{1,5}$ Ryan W. McCarthy, ${ }^{1,2}$ Patrick J. Whelan, ${ }^{1,3}$ Michael C. Antle, ${ }^{1,4,5}$ \\ Quentin J. Pittman, ${ }^{1,4}$ and G. Campbell Teskey ${ }^{1,4,5,6}$ \\ ${ }^{1}$ Hotchkiss Brain Institute, Departments of ${ }^{2}$ Neuroscience, ${ }^{3}$ Comparative Biology and Experimental Medicine, ${ }^{4}$ Physiology and Pharmacology, ${ }^{5}$ Psychology, \\ and ${ }^{6}$ Cell Biology and Anatomy, University of Calgary, Calgary, Alberta, Canada T2N 4N1
}

Serotonin has a myriad of central functions involving mood, appetite, sleep, and memory and while its release within the spinal cord is particularly important for generating movement, the corresponding role on cortical movement representations (motor maps) is unknown. Using adult rats we determined that pharmacological depletion of serotonin (5-HT) via intracerebroventricular administration of 5,7 dihydroxytryptamine resulted in altered movements of the forelimb in a skilled reaching task as well as higher movement thresholds and smaller maps derived using high-resolution intracortical microstimulation (ICMS). We ruled out the possibility that reduced spinal cord excitability could account for the serotonin depletion-induced changes as we observed an enhanced Hoffman reflex (H-reflex), indicating a hyperexcitable spinal cord. Motor maps derived in $5-\mathrm{HT}_{1 \mathrm{~A}}$ receptor knock-out mice also showed higher movement thresholds and smaller maps compared with wild-type controls. Direct cortical application of the 5-HT ${ }_{1 \mathrm{~A} / 7}$ agonist 8-0H-DPAT lowered movement thresholds in vivo and increased map size in 5-HT-depleted rats. In rats, electrical stimulation of the dorsal raphe lowered movement thresholds and this effect could be blocked by direct cortical application of the 5- $\mathrm{HT}_{1 \mathrm{~A}}$ antagonist WAY-100135, indicating that serotonin is primarily acting through the $5-\mathrm{HT}_{1 \mathrm{~A}}$ receptor. Next we developed a novel in vitro ICMS preparation that allowed us to track layer V pyramidal cell excitability. Bath application of WAY-100135 raised the ICMS current intensity to induce action potential firing whereas the agonist 8-0H-DPAT had the opposite effect. Together our results demonstrate that serotonin, acting through 5-HT $1 \mathrm{~A}$ receptors, plays an excitatory role in forelimb motor map expression.

\section{Introduction}

Motor maps are topographical representations of movements in the motor cortex (Ferrier, 1873). When motor map integrity is disrupted, behavioral deficits are observed (Whishaw, 2000). Motor maps show plasticity and their expression changes following skilled motor learning and in neuropathophysiological conditions (Kleim et al., 1998, 2002, 2004). These experiencedependent changes to map expression are in part due to modulation of cortical synaptic connections and neuronal excitability (Hess and Donoghue, 1994; Monfils et al., 2004) particularly of layer $\mathrm{V}$ pyramidal neurons that make up the corticospinal tract

\footnotetext{
Received Sept. 4, 2012; revised Dec. 14, 2012; accepted Feb. 1, 2013.

Author contributions: K.S., J.A.B., S.T.N., P.J.W., M.C.A., Q.J.P., and G.C.T. designed research; K.S., J.A.B., G.R.Y., J.T.G.R., S.T.N., A.S., V.M.S., R.W.M., and M.C.A. performed research; K.S., J.A.B., G.R.Y., J.T.G.R., S.T.N., A.S., V.M.S., M.C.A., and G.C.T. analyzed data; K.S., J.A.B., J.T.G.R., S.T.N., A.S., V.M.S., R.W.M., P.J.W., M.C.A., Q.J.P., and G.C.T. wrote the paper.

This work is supported by funding from Natural Sciences and Engineering Research Council of Canada to M.C.A., G.C.T., and Q.J.P.; Canadian Institute for Health Research to P.J.W., Q.J.P., and G.C.T.; and Alberta Innovates-Health Solutions to P.J.W., Q.J.P., and K.S. Knock-out mice were provided by Dr. Miklos Toth (Cornell University Medical College, New York). Thanks to Lorenzo Bauce for carrying out the HPLC analysis.

*K.S. and J.A.B. contributed equally to this work.

The authors declare no competing financial interests.

Correspondence should be addressed to G.C. Teskey, Hotchkiss Brain Institute, Department of Cell Biology and Anatomy, Faculty of Medicine, University of Calgary, Health Sciences Centre, 3330 Hospital Drive NW, Calgary, Alberta, Canada T2N 4N1. E-mail: gteskey@ucalgary.ca.

DOI:10.1523/JNEUROSCI.4241-12.2013

Copyright $\odot 2013$ the authors $\quad 0270-6474 / 13 / 334988-12 \$ 15.00 / 0$
}

(Young et al., 2011). Enhancing cortical inhibition decreases motor map size and increases movement thresholds (Teskey et al., 2007; Young et al., 2011), whereas enhancing cortical excitability through elicitation of seizures has the opposite effect (Henderson et al., 2011). Previous studies have shown that several neuromodulators alter cortical motor map expression, including dopamine (Metz et al., 2004; Brown et al., 2009, 2011) and acetylcholine (Conner et al., 2003, 2010; Ramanathan et al., 2009).

Serotonin (5-hydroxytryptamine; 5-HT), a classic small molecule neurotransmitter, is synthesized in the raphe nuclei, which send widespread serotonergic projections throughout the brain and spinal cord (Moore et al., 1978; Bowker et al., 1983). Electrophysiological studies have demonstrated that bath application of serotonin to the isolated spinal cord causes fictive locomotion (Cazalets et al., 1992; Cowley and Schmidt, 1997; Hochman and Schmidt, 1998; Madriaga et al., 2004), indicating that serotonin is important for movement (Schmidt and Jordan, 2000). Surprisingly, the role of 5-HT on motor map expression has not been addressed, despite serotonin's fundamental and influential role on cortical mechanisms of movement (Vanderwolf, 1989) and its dense projections to the cortex from the median and dorsal raphe (Moore et al., 1978). A role in motor map expression would indicate a novel role for 5-HT in motor control beyond the direct raphe projections to the ventral horn of the spinal cord.

Postsynaptic serotonin signaling in the cortex relies primarily on inhibitory G-protein-coupled 5- $\mathrm{HT}_{1 \mathrm{~A}}$ receptors (Barnes and 
Sharp, 1999); these are found on both GABAergic interneurons (Kruglikov and Bernardo, 2008) and layer V pyramidal cells (Puig et al., 2005), therefore calling for an empirical determination of serotonin's overall contribution to network excitability. To test the hypothesis that serotonin alters the expression of forelimb motor maps we used three approaches: (1) we interfered with 5-HT action, by depletion with intracerebroventricular injection of 5,7 dihydroxytryptamine (5,7 DHT), and local cortical application of the serotonin antagonist WAY-100135 in rats, and by using $5-\mathrm{HT}_{1 \mathrm{~A}} \mathrm{R}$ knock-out (KO) mice; (2) serotonin release was activated within cortical networks by stimulation of the dorsal raphe and by local cortical application of the $5-\mathrm{HT}_{1 \mathrm{~A} / 7}$ serotonin agonist 8-OH-DPAT; and (3) we observed separately the effects of 8-OH-DPAT and the 5-HT ${ }_{1 \mathrm{~A}}$ antagonist WAY-100135 on electrophysiological properties of layer $\mathrm{V}$ pyramidal cells using a novel in vitro slice technique that replicates the essential methodological features of the intracortical microstimulation (ICMS) paradigm. Our results indicate that inhibition of 5- $\mathrm{HT}_{1 \mathrm{~A}}$ receptor signaling suppresses motor map expression and has a deleterious effect on skilled motor behavior.

\section{Materials and Methods}

Rodents. Adult male Hooded Long-Evans (LE) rats $(n=112)$ and $5-\mathrm{HT}_{1 \mathrm{~A}}$ receptor $\mathrm{KO}(n=5)$, heterozygous $(n=5)$, and wild-type (WT) mice $(n=5)$ were used in this study. All rats were obtained from Charles River. Mice were generated in a breeding colony maintained by Dr. Michael Antle at the University of Calgary from mice initially developed by Dr. Thomas Shenk (Princeton University, Princeton, NJ), and were bred on the C57BL/6J background. Information about the generation of the 5- $\mathrm{HT}_{1 \mathrm{~A}}$ receptor KO mice can be found in Parks et al. (1998). The three genotypes of mice were produced by heterozygous $x$ heterozygous crosses with two exceptions, two mice that came from a heterozygous $X$ homozygous cross. All offspring were genotyped using a pair of $\mathrm{KO}$ primers (amplifying a $400 \mathrm{bp}$ product that contains a piece of the neomycin cassette that replaced the start codon of the $5-\mathrm{HT}_{1 \mathrm{~A}}$ receptor gene) as well as a pair of WT primers (amplifying a 238 bp product that contains a segment of the 5- $\mathrm{HT}_{1 \mathrm{~A}}$ receptor gene replaced by the neomycin cassette in the $\mathrm{KO}$ animals) to identify the presence or absence of each allele of the 5- $\mathrm{HT}_{1 \mathrm{~A}}$ receptor gene (KO up primer: CTT TAC GGT ATC GCC GCT CCC GAT TC; KO down primer: TGC AGG ATG GAC GAA GTG CAG CAC A; WT up primer: AGTGCA GGC AGG CAT GGA TAT GTT; WT down primer: CCG ATGAGA TAG TTG GCA ACA TTC TGA; Smith et al., 2008).

Rats were housed individually and mice were group housed (up to five mice per cage) in clear plastic cages and were maintained on a $12 \mathrm{~h}$ light/dark cycle, lights on at 07:00 h, in separate colony rooms under specified pathogen-free conditions. Food and water were available ad libitum. All experimental procedures occurred during the light phase. Rodents were handled and maintained according to the Canadian Council for Animal Care guidelines. These procedures were approved by the Life and Environmental Sciences Animal Care and Health Sciences Animal Care Committees at the University of Calgary.

Drugs. All drugs were obtained through Sigma-Aldrich. Drugs for ICMS experiments were dissolved in physiological saline, whereas drugs for cell recordings were dissolved as stock solutions in distilled $\mathrm{H}_{2} \mathrm{O}$ and stored at $-20^{\circ} \mathrm{C}$ until use. 5,7 DHT creatinine sulfate salt was dissolved with $0.1 \%$ ascorbic acid. Desipramine hydrochloride was used at a dosage of $25 \mathrm{mg} / \mathrm{kg}$ and given in a volume of $1 \mathrm{ml} / \mathrm{kg}$. The $5-\mathrm{HT}_{1 \mathrm{~A}}$ antagonist WAY-100135 maleate salt was used at a concentration of $6 \mu \mathrm{M}(2 \mu \mathrm{l} /$ injection site, total volume $6 \mu \mathrm{l}$ ) for ICMS procedures and $10 \mu \mathrm{M}$ for bath application during cell recordings. The $5-\mathrm{HT}_{1 \mathrm{~A} / 7}$ agonist $(\mathrm{R})-(+)-8-$ hydroxy-2-(di-n-propylamino)tetralin (8-OH-DPAT) was used at a concentration of $80 \mu \mathrm{M}(\sim 0.5 \mathrm{ml}$ to cover the ICMS window as needed) for ICMS procedures and $10 \mu \mathrm{M}$ for bath application during cell recordings.

5-HT depletion surgery. To infer a role for serotonin in both forelimb motor map expression and learning to use the forelimb in a task requiring skill, we induced a widespread depletion of serotonin by injecting the specific neurotoxin 5,7 DHT into a lateral ventricle according to the methodology of Hall et al. (1999). Thirty minutes before surgery, adult male LE rats received an intraperitoneal injection of desipramine hydrochloride $(25 \mathrm{mg} / \mathrm{kg})$ to protect the noradrenergic system. Rats were then anesthetized using isoflurane (5\% induction). The incision site was shaved and the rat was placed into a stereotaxic apparatus with a flat skull position (incisor bar set $3.4 \mathrm{~mm}$ below the intra-aural plane). A subcutaneous injection of lidocaine was administered to the incision site $2 \mathrm{~min}$ before performing the incision. The connective tissue was removed from the skull and a small hole was drilled. To deplete serotonin rats received a $10 \mu$ intracerebroventricular (anterior-posterior: $+0.8 \mathrm{~mm}$, mediolateral: $+1.5 \mathrm{~mm}$, dorsoventral: $-3.5 \mathrm{~mm}$, with respect to bregma) injection of 5,7 DHT $(40 \mu \mathrm{g} / 1 \mu \mathrm{l}$ of $0.1 \%$ ascorbic acid/physiological saline solution), using a $10 \mu \mathrm{l} 30$ gauge Hamilton microsyringe. The rate of infusion was $2 \mu \mathrm{l} / \mathrm{min}$. The syringe was left in place for $2 \mathrm{~min}$ after the infusion to aid in diffusion, after which it was carefully removed. Bone wax was then used to occlude the drill hole. The scalp was then sutured and lidocaine jelly was applied to the incision site. Rats were then returned to their home cage.

HPLC in the forelimb motor neocortex. At the end of a two-week recovery period ( $\operatorname{control} n=5$; lesion $n=5$ ) we used HPLC to determine the extent to which intracerebroventricular administration of 5,7 DHT reduced serotonin in motor cortex. Rats were deeply anesthetized with sodium pentobarbital and were transcardially perfused with cold $0.1 \mathrm{M}$ phosphate buffering saline (PBS). The brains were then extracted and the left motor cortex $(\sim 4 \mathrm{~mm}$ anterior and $3 \mathrm{~mm}$ posterior to bregma and 5 $\mathrm{mm}$ lateral to midline, encompassing the caudal forelimb area (CFA) as well as rostral forelimb area; RFA) was dissected and found to weigh between 93 and $135 \mathrm{mg}$. The dissected brain tissue was then placed in a polypropylene tube and placed on ice until it was used in HPLC analysis.

HPLC was performed according to the methodology of Horn et al. (1995). Ice-cold $0.2 \mathrm{~m}$ perchloric acid was used to homogenize the cortical tissue in a total volume of $500 \mu \mathrm{l}$ (weight of cortex + volume of $0.2 \mathrm{M}$ perchloric acid $=500 \mu \mathrm{l}$ ) for $30 \mathrm{~s}$ with an IKA Ultra Turrax homogenizer. The homogenate was centrifuged at $10,000 \mathrm{rpm}$ at $4^{\circ} \mathrm{C}$ for $20 \mathrm{~min}$. Aliquots of the supernatant $(100 \mu \mathrm{l})$ were injected into a liquid chromatograph running a mobile phase of $100 \mathrm{~nm}$ ammonium dihydrogen phosphate, $2 \mathrm{~mm}$ sodium dodecylsulfate, $2 \mathrm{~mm}$ citric acid, $0.5 \mathrm{~mm}$ disodium EDTA in $90 \%$ water, and $10 \%$ methanol flowing at a rate of 1 $\mathrm{ml} / \mathrm{min}$ over a Varian Micro-Pak C18-5 Column $(4 \times 100 \mathrm{~mm}, \mathrm{C}-18$ reverse phase, $5 \mu \mathrm{m}$ particle size). A BAS LC- $4 \mathrm{~b}$ amperometric detector with a glassy carbon electrode held at $+0.75 \mathrm{~V}$ was used to detect monoamines in the samples. A Waters Maxima data acquisition system was used to digitize and store the oxidation signal. The stored data were quantified using the external standard method, using fresh standards in $0.2 \mathrm{~m}$ perchloric acid. The detection limit was $1 \mathrm{pmol}$ injected on column (Horn et al., 1995). Data were then converted to $\mathrm{pmol} / \mathrm{mg}$ tissue by multiplying by five (to correct for HPLC tissue processing) and then dividing by the tissue weight.

Tryptophan hydroxylase (TPH) immunohistochemistry and cell counting in the dorsal and median raphe. We were also interested in determining the amount of cell loss in response to the intracerebroventricular administration of 5,7 DHT in the dorsal and median raphe, as both of these nuclei provide serotonergic projections to forebrain structures. Once the left motor cortex was dissected for HPLC, the remaining brain tissue was postfixed in $4 \%$ paraformaldehyde (PFA) for $48 \mathrm{~h}$. The brains were then transferred to a $30 \%$ sucrose solution for $48 \mathrm{~h}$ for cryoprotection. An alternate series of $50 \mu \mathrm{m}$ coronal sections were cut on a cryostat and collected throughout the rostrocaudal extent of the dorsal and median raphe. Sections were deposited into wells containing $0.1 \mathrm{M}$ PBS with $0.02 \%$ sodium azide. Sections were rinsed in $0.5 \%$ hydrogen peroxide in PBSx $(0.3 \%$ Triton X-100 in $0.1 \mathrm{~m}$ PBS) for 15 min to inactivate endogenous peroxidases. The sections were rinsed in PBSx, and were then blocked using 4\% normal goat serum (NGS; Vector Laboratories) in PBSx for $90 \mathrm{~min}$, after which the sections were incubated in a mouse anti-TPH primary antibody (1:5000; Sigma-Aldrich) in 1\% NGS in PBSx for $48 \mathrm{~h}$ at $4^{\circ} \mathrm{C}$ on a shaker tray. Sections were rinsed again and then incubated in a biotinylated goat anti-mouse secondary antibody (1:200; Vector Laboratories) for $60 \mathrm{~min}$. The sections were thoroughly rinsed 
again and then incubated in an avidin-biotin complex (1:100; Vector Vectastain Elite ABC kit; Vector Laboratories) for $60 \mathrm{~min}$, before being rinsed a final time, and reacted in a solution containing $24 \mathrm{ml}$ of $0.1 \mathrm{M}$ Tris buffer, $1 \mathrm{ml}$ of 3,3' diaminobenzidine tetrahydrochloride (DAB) solution ( $4 \mathrm{mg} / \mathrm{ml}, 0.4 \%$ solution), with $60 \mu \mathrm{l}$ of $8 \%$ nickel chloride to intensify the reaction product and $80 \mu \mathrm{l}$ of $30 \%$ hydrogen peroxide. The DAB reaction was quenched in a rapid series of PBSx rinses and sections were mounted on gelatin-coated slides, which were air dried and then dehydrated in alcohol rinses $(70,95$, and 100\% ethanol), cleared with xylene and coverslipped with Permount (Fisher Scientific).

Quantification was performed by counting the number of TPHpositive cells in the median and dorsal raphe nuclei and averaging over groups. Pictures of the raphe sections were taken with an Olympus BX51 microscope equipped with a QImaging QICAM 1394 camera using ImagePro Plus software (Media Cybernetics). Three (anterior, medial, and posterior) separate sections, $50 \mu \mathrm{m}$ each, through the raphe nuclei between 7.3 and $8.3 \mathrm{~mm}$ posterior from bregma were used for analysis for each rat. Cell counts from each of the three sections were performed using the cell counter plugin to ImageJ (National Institutes of Health). TPH-positive neurons were defined as being densely stained cell bodies that were visible on the sections.

Single pellet skilled reaching task. Previous research examining the effect of serotonin depletion on motor performance has found little, if any, effect on performance in sensorimotor tasks (Vanderwolf, 1989; Dringenberg et al., 1995; Gharbawie and Whishaw, 2003). To determine the effect of the serotonergic lesion on learning a task involving skilled use of the forelimb, we trained rats on the single pellet reaching task (Whishaw et al., 2003). This task requires learning to reach for a sugar pellet through a narrow slit in the apparatus. Rats were food restricted to $85-90 \%$ of free-feeding levels and given several banana flavored sucrose pellets ( $90 \mathrm{mg}$ of Rodent Chow food pellets; Bioserve) before pretraining to ensure motivation and to familiarize them to the novel food. LE adult rats (control $n=12$, lesion $n=12$ ) were then pretrained in the single pellet skilled reaching task to determine handedness, and then received 5,7 DHT to the ventricle ipsilateral to the preferred forelimb to induce a serotonergic lesion. Reach training began $48 \mathrm{~h}$ after the lesion surgery and continued for a total of 10 daily sessions. We measured the number of reach attempts and percentage success on each training session. On the last session, the qualitative aspects of the 10 discrete subcomponents of the reaching behavior were also assessed. All apparatus, training methods, and analysis have been described previously (Whishaw et al., 2003; Henry et al., 2008).

ICMS. Standard high-resolution ICMS techniques were used to produce detailed threshold maps of forelimb regions of the motor cortex (Nudo et al., 1990; Kleim et al., 1998; Young et al., 2011). Twenty-four hours before surgery, rats were food deprived. Rats were initially anesthetized with intraperitoneal ketamine $(100 \mathrm{mg} / \mathrm{kg})$ and xylazine $(5 \mathrm{mg} /$ $\mathrm{kg})$. Supplemental injections of either ketamine $(25 \mathrm{mg} / \mathrm{kg})$ or a mixture of ketamine $(17 \mathrm{mg} / \mathrm{kg})$ and xylazine $(2 \mathrm{mg} / \mathrm{kg})$ were given as needed to maintain a light anesthesia level. Mice were initially anesthetized with an intraperitoneal injection of ketamine $(25 \mathrm{mg} / \mathrm{kg})$ and xylazine $(2.5 \mathrm{mg} /$ $\mathrm{kg})$. Supplemental injections of either ketamine $(10 \mathrm{mg} / \mathrm{kg})$ or a mixture of ketamine $(10 \mathrm{mg} / \mathrm{kg})$ and xylazine $(1 \mathrm{mg} / \mathrm{kg})$ were given as required to maintain a constant level of anesthesia. Level of anesthesia was monitored by assessment of breathing rate, whisker movements, and withdrawal reflex from a light pinch to the foot (rats) and tail (mice).

A craniotomy was performed to expose the motor cortex of the left hemisphere or the hemisphere contralateral to the preferred forelimb in the reaching experiment. The craniotomy extended $\sim 4 \mathrm{~mm}$ anterior and $3 \mathrm{~mm}$ posterior from bregma, and extended $\sim 5 \mathrm{~mm}$ lateral from the midline in rats. The craniotomy window in mice extended $\sim 4 \mathrm{~mm}$ anterior and $3 \mathrm{~mm}$ posterior from bregma, and $3 \mathrm{~mm}$ lateral from midline. The cisterna magna was punctured with an 18-gauge needle to reduce brain swelling, and the dura matter was carefully removed from the neocortex. Silicon liquid warmed to body temperature $\left(37-38^{\circ} \mathrm{C}\right)$ was placed on the exposed cortex, except when drugs were applied to the surface. A photograph magnified $32 \times$ was taken using a digital camera connected to a stereomicroscope, which was then displayed on a personal computer. Using Canvas (version 11) imaging software (ACD Systems of
America), a grid consisting of $500 \mu \mathrm{m}$ squares was placed over the digital image. Electrode penetration occurred at the corners and middle of these squares unless there was a blood vessel, in which case no penetration occurred.

Electrodes pulled from glass capillary tubes were beveled and filled with $3.5 \mathrm{M}$ sodium chloride and had impedance values of 1.0-1.5 M $\Omega$. From the surface of the brain the electrode was lowered to a depth of 1550 $\mu \mathrm{m}$ for rats and $800 \mu \mathrm{m}$ for mice, which corresponds to layer $\mathrm{V}$ of the cortex. Stimulation consisted of 13 monophasic $200 \mu$ s cathodal pulses at $300 \mathrm{~Hz}$ (Young et al., 2011).

Rodents were maintained in the prone position, with their forelimb supported by a finger, elevating the limb for a closer inspection of possible movements. A threshold was determined at each penetration site. This was done by quickly increasing the current from $0 \mu \mathrm{A}$ toward $60 \mu \mathrm{A}$ until a movement was noted. The current was then decreased until the movement ceased. The movement threshold was defined as the minimal ICMS current able to elicit a movement. If the maximal current of $60 \mu \mathrm{A}$ was unable to elicit a movement, then the penetration site was considered nonresponsive.

First, the border of the motor map was defined with nonforelimb (hindlimb, jaw, neck, tail, trunk, and whisker) and nonresponsive points. Once the border was complete the forelimb (digit, wrist, elbow, shoulder) area was determined. Positive response sites were revisited during surgery to assay for changes in movement threshold as an indicator for anesthesia levels.

Motor maps were analyzed using Canvas software to calculate the areal extent of the RFA and CFA, respectively.

Spinal cord excitability at the forelimb level. Given that serotonin regulates spinal cord excitability and that a loss of function at the spinal cord level could account for our motor map findings, we examined the H-reflex using methods modified by Lee et al. (2005). Six ( $\operatorname{control} n=3$; lesion $n=3$ ) adult male LE rats were anesthetized by an intraperitoneal injection of ketamine $(100 \mathrm{mg} / \mathrm{kg})$ and xylazine $(5 \mathrm{mg} / \mathrm{kg})$ and supplemented as needed with ketamine $(25 \mathrm{mg} / \mathrm{kg})$. Forelimbs were dissected to expose the median and ulnar nerves and isolate them from surrounding tissue to permit the placement of custom-made bipolar, silver stimulating hook electrodes under the nerves. Mineral oil was applied occasionally to prevent tissue desiccation. Acute electromyogram (EMG) recording electrodes (E2 subdermal needle electrodes; Grass Instrument Company) were inserted into the first dorsal interosseus. Bipolar stimulation was delivered by Clampex 10 via a Digidata 1440A (Molecular Devices) triggering a stimulation isolation unit (Stimulus Isolator A365; World Precision Instruments) connected to the bipolar stimulating electrode. Stimulation threshold ( $\sim 50-75 \mu \mathrm{A}, 0.2 \mathrm{~ms}$ pulse duration) was measured for each animal by finding the minimum stimulation current sufficient to consistently evoke a short-latency, muscle compound action potential (AP; M-wave). After defining the stimulation threshold, the effects of various frequencies $(0.1-2.0 \mathrm{~Hz})$ and stimulation strengths (1.0-2.0 times threshold) on afferent-evoked muscle activity (H-reflex amplitude) were recorded to evaluate possible changes in spinal cord excitability caused by 5 -HT depletion. The M-wave response was monitored during the $\mathrm{H}$-reflex recording to confirm the stability and intensity of the electrical stimulation throughout the experiment. EMG recordings were amplified $(10 \times$ headstage, $200 \times$ amplifier, $2000 \times$ total $)$ and filtered (low cut $300 \mathrm{~Hz}$, high cut $3 \mathrm{kHz}, \mathrm{EX} 4-400$, Dagan) and then recorded and stored on PC for off-line analysis (10 kHz sampling rate, Clampex 10 and Clampfit; Molecular Devices). H-reflex amplitudes were measured from peak to peak.

Dorsal raphe electrode implantation surgery and stimulation parameters. Adult male LE hooded rats $(n=8)$ were anesthetized with $2-5 \%$ isoflurane. The heads were shaved and they were mounted in a stereotaxic frame. The skull was leveled between bregma and lambda. A twisted, Teflon-coated, bipolar electrode was chronically implanted into the dorsal raphe nucleus (DRN; coordinates: on midline, $7.3 \mathrm{~mm}$ posterior to and $6.0 \mathrm{~mm}$ ventral to bregma). The electrode assembly was anchored to the head using jeweler's screws and dental acrylic. ICMS was performed on the rats 1 week post-surgery.

Electrical current was delivered by a Grass S88x stimulator via a Grass SIU-C stimulus isolation unit (Astro-Med). Stimulation consisted of bi- 
phasic $100 \mu$ s square wave pulses that were delivered at $20 \mathrm{~Hz}$. Dorsal raphe stimulation during ICMS was conducted at an intensity of $200 \mu \mathrm{A}$ for $90 \mathrm{~s}$.

Rat ICMS with raphe stimulation and following $5-H T_{1 A}$ receptor antagonist application. We electrically stimulated the dorsal raphe to directly observe the effect of serotonin release in the motor cortex on movement thresholds. Fifteen forelimb responsive sites, five nonresponsive and nonforelimb sites, were located for each rat. Movement thresholds were obtained three times at all electrode penetration sites. At each site, movement thresholds were taken before (prestimulation), during (stimulation), and after dorsal raphe stimulation (post stimulation). After the prestimulation movement threshold was determined, the dorsal raphe was stimulated for $90 \mathrm{~s}$ with the stimulation movement threshold taken within the last $10 \mathrm{~s}$. The third movement threshold was taken $3 \mathrm{~min}$ following termination of dorsal raphe stimulation (poststimulation condition). Thus the movement threshold at each penetration point was derived three times over $\sim 5$ min before moving on to the next point.

To determine whether the serotonin released in the motor cortex in response to dorsal raphe stimulation was acting through the $5-\mathrm{HT}_{1 \mathrm{~A}}$ receptor we applied the specific antagonist WAY-100135. Once all forelimb, nonforelimb responsive points and nonresponsive points had been determined using the ICMS technique, the $5-\mathrm{HT}_{1 \mathrm{~A}}$ receptor antagonist WAY-100135 (6 $\mu \mathrm{M}$ solution in a volume of $2 \mu \mathrm{l}$ over 2 min per site; Lanfumey et al., 1993) or vehicle (physiological saline) was infused into the neocortex (layer V; $1.5 \mathrm{~mm}$ below cortex surface) at three sites: (1) medial, (2) anterior, (3) lateral to the forelimb responsive points. The needle was left in place for $2 \mathrm{~min}$ after the infusion. All ICMS sites were revisited twice. The thresholds for the prestimulation condition (with WAY-100135 or vehicle) were taken after the three injections of WAY100135 or vehicle. After all the prestimulation thresholds were determined, the dorsal raphe was again stimulated for $90 \mathrm{~s}$ with the stimulation condition (with WAY-100135 or vehicle) thresholds taken within the last $10 \mathrm{~s}$.

Histology. Immediately following ICMS rats were transcardially perfused with PBS and then with 4\% PFA. The brains were then removed and postfixed in PFA for $24 \mathrm{~h}$. The brains were cryoprotected by immersion in a $30 \%$ sucrose solution for $48 \mathrm{~h}$. Slices $(50 \mu \mathrm{m})$ spanning the rostrocaudal extent of the dorsal and median raphe were collected using a cryostat and were stained with cresyl violet to determine electrode placement. Only rats that had the tip of the electrode in the DRN were used for analysis.

Rat ICMS with 5-HT $T_{1 A / 7}$ receptor agonist application. A final in vivo experiment was performed to determine whether the serotonin agonist 8-OH-DPAT, acting through the $5-\mathrm{HT}_{1 \mathrm{~A}}$, receptor also had the predicted effect of lowering ICMS-elicited movement thresholds. In adult male LE rats (control $n=9$; lesion $n=8$ ), ICMS was performed to derive a baseline motor map. Following the baseline ICMS mapping either 8-OHDPAT solution ( $80 \mu \mathrm{M}$ in a volume of $\sim 0.5 \mathrm{ml}$ of physiological saline) or vehicle was then applied directly to the surface of the neocortex. Thirty minutes later the motor cortex was remapped.

ICMS in slice electrophysiology. In the last two experiments we developed a novel in vitro slice technique that replicates the essential methodological features of the ICMS paradigm. We then observed separately the effects of 8-OH-DPAT and the 5- $\mathrm{HT}_{1 \mathrm{~A}}$ antagonist WAY-100135 on the electrophysiological properties of layer $\mathrm{V}$ pyramidal cells subjected to slice ICMS. Seventeen male LE rats (postnatal day 34-39) were anesthetized using isoflurane and then decapitated. Using a methodology modified by Galic et al. (2008), the brain was quickly removed and placed in ice-cold slicing solution for several minutes containing the following (in mu): $87 \mathrm{NaCl}, 2.5 \mathrm{KCl}, 25 \mathrm{NaHCO}_{3}, 0.5 \mathrm{CaCl}_{2}, 7 \mathrm{MgCl}_{2}, 1.25 \mathrm{NaH}_{2} \mathrm{PO}_{4}$, 25 glucose, and 75 sucrose, saturated with $95 \% \mathrm{O}_{2} / 5 \% \mathrm{CO}_{2}$. The brain was then blocked and mounted on a vibratome (Leica) and submerged in ice-cold slicing solution. Coronal slices $(300 \mu \mathrm{m})$ containing motor cortex were taken from a region extending $\sim 600 \mu \mathrm{m}$ anterior and $\sim 300 \mu \mathrm{m}$ posterior to bregma. Slices were then incubated at $32^{\circ} \mathrm{C}$ for $30 \mathrm{~min}$ in artificial CSF (aCSF) containing the following (in $\mathrm{mM}$ ): $126 \mathrm{NaCl}, 2.5$ $\mathrm{KCl}, 26 \mathrm{NaHCO}_{3}, 2.5 \mathrm{CaCl}_{2}, 1.5 \mathrm{MgCl}_{2}, 1.25 \mathrm{NaH}_{2} \mathrm{PO}_{4}$, and 10 glucose, saturated with $95 \% \mathrm{O}_{2} / 5 \% \mathrm{CO}_{2}$. Following incubation, slices were maintained in aCSF at room temperature $\left(21-24^{\circ} \mathrm{C}\right)$ for a minimum of $30 \mathrm{~min}$ before recording. Slices containing motor cortex were transferred to a recording chamber and superfused with $32^{\circ} \mathrm{C}$ aCSF at a flow rate of $1-2$ $\mathrm{ml} / \mathrm{min}$.

Whole-cell recordings were obtained from layer $\mathrm{V}$ pyramidal cells visualized with an AxioskopII FS Plus upright microscope (Zeiss) with a $40 \times$ objective using infrared differential interference contrast optics. Layer V pyramidal cells were identified based on their tear-drop/triangular morphology with large apical dendrites orientated to the pial surface as well as electrophysiological characteristics (Bandrowski et al., 2003; Brill and Huguenard, 2010). Whole-cell recordings were obtained using borosilicate glass microelectrodes (tip resistance 3-5 M $\Omega$ ) filled with a solution containing the following (in $\mathrm{mM}$ ): $108 \mathrm{~K}$-gluconate, 8 Na-gluconate, $2 \mathrm{MgCl}_{2}, 8 \mathrm{KCL}, 1 \mathrm{~K}_{2}$-EGTA, $4 \mathrm{~K}_{2}$-ATP, $0.3 \mathrm{Na}_{3} \mathrm{GTP}$, and 10 HEPES that was corrected to $\mathrm{pH} 7.25$ with $\mathrm{KOH}$. Membrane potentials were corrected for a liquid junction potential of $12 \mathrm{mV}$ and subsequent voltages include liquid junction potential correction. Recordings were accepted for analysis if series resistance was $<20 \mathrm{M} \Omega$ and changes in series resistance were $<20 \%$ throughout the experiment. Electrophysiological signals were amplified using the Multiclamp 700A amplifier (Molecular Devices), low-pass filtered at $1 \mathrm{kHz}$, and digitized at $10 \mathrm{kHz}$ using a Digidata 1322A (Molecular Devices). Data were collected (pClamp 9.0, Molecular Devices) and stored on a computer for offline analysis using Clampfit 9.0 (Molecular Devices).

Input resistance was measured as the slope of regression lines of plots of voltage responses to a family of $10 \mathrm{pA}$ current steps. Intrinsic AP threshold was measured in response to a depolarizing current ramp and analyzed using Mini Analysis Software (Synaptosoft). Current-clamp recordings $(I=0)$ were used to assess layer $\mathrm{V}$ pyramidal cells' responses during stimulation of the slice, with parameters that are typical of the intracortical microstimulation used to assess movement representations in anesthetized rodents (Flynn et al., 2010; Brown et al., 2011; Tennant et al., 2011; Young et al., 2011). Slices were stimulated extracellularly with a patch pipette containing aCSF that was positioned directly dorsal $(\sim 130$ $\mu \mathrm{m}$ ) to each layer $\mathrm{V}$ pyramidal cell body before recording from the latter in whole-cell configuration (preparation termed slice-ICMS). Electrical stimulation was delivered to the slice via an isolated stimulator (A-M Systems) and consisted of 13 monophasic cathodal pulses, each $200 \mu \mathrm{s}$ in duration, delivered at a frequency of $300 \mathrm{~Hz}$, and repeated every second. Slice-ICMS current intensity was manually increased from 0 to $60 \mu \mathrm{A}$, in $5 \mu \mathrm{A}$ increments each delivered for $10 \mathrm{~s}$ (i.e., each $5 \mu \mathrm{A}$ increment was administered for $101 \mathrm{~Hz}$ trains with each $1 \mathrm{~Hz}$ train consisting of 13 pulses). Pyramidal cell responses to slice-ICMS were assessed with four measures: (1) the resting membrane potential (RMP), (2) the minimum intensity of slice-ICMS current needed to evoke an AP (referred to as first AP discharge), (3) the percentage of cells exhibiting $\geq 1$ AP at each sliceICMS $5 \mu \mathrm{A}$ increment, and (4) the total number of APs at each sliceICMS $5 \mu \mathrm{A}$ increment. All four slice-ICMS responses were assessed before and after bath application of either 8-OH-DPAT or WAY-100135.

Statistics. A Kruskal-Wallis test was conducted to assess treatment effects on cortical monoamine levels. Immunohistochemistry, behavior (percentage success and number of reach attempts), and H-reflex amplitudes were analyzed using separate independent samples $t$ tests. Frequency amplitude modulation, reach attempts, and reaching success were each analyzed using a two-way ANOVA with Bonferroni post hoc comparisons. Independent samples $t$ tests were used to compare movement thresholds between control and 5-HT-depleted rats, as well as control plus reach and 5-HT-depleted and reach-trained rats. To determine differences in motor maps between control, 5-HT-depleted, control and reach-trained, and 5-HT-depleted and reach-trained rats, a two-way ANOVA test with simple main effects was used. Map-remap data were analyzed using either a paired samples $t$ test (map size) or the Wilcoxon signed ranks test (thresholds). A Wilcoxon matched-pair signed ranks test for planned comparisons with Bonferroni adjusted $p$ values was used to compare thresholds taken during the prestimulation, stimulation, and stimulation + WAY-100135 conditions. An ANOVA test with a Tukey HSD post hoc was used to determine any differences in movement thresholds and motor maps between WT, heterozygous, and KO mice. For slice-ICMS, cell recordings were averaged across neurons for each condition. Significance was determined using a Student's $t$ test or ANOVA 
Table 1. Amount (pmol/mg) of five metabolites in the motor cortex

\begin{tabular}{llllll}
\hline Treatment & 5 -HT & 5-HIAA & $\mathrm{NE}$ & $\mathrm{DA}$ & DOPAC \\
\hline Control & $1.06 \pm 0.21$ & $0.25 \pm 0.17$ & $1.66 \pm 0.31$ & $0.22 \pm 0.11$ & $0.50 \pm 0.17$ \\
5,7 DHT & $0.00^{*}$ & $0.13 \pm 0.13$ & $1.13 \pm 0.25$ & $0.12 \pm 0.03$ & $0.37 \pm 0.11$
\end{tabular}

Asterisk ${ }^{*}$ ) indicates being significantly different from control at $p<0.05 .5$-HIAA, 5 -Hydroxyindoleacetic acid; DA, dopamine, DOPAC, 3,4-dihyroxyphenylacetic acid; NE, norepinephrine.

with post hoc comparisons based on what was appropriate for the number of conditions and/or measurements. A paired two-tail Student's $t$ test was used to assess differences in intrinsic membrane properties. A Wilcoxon signed rank one-tail test was used to assess differences in the number of APs elicited at each $5 \mu \mathrm{A}$ current increment for slice-ICMS. An $\alpha$ value of 0.05 was used in all experiments and all statistical analyses were conducted using Statistical Package for the Social Sciences (IBM SPSS). Data are presented as mean \pm SEM.

\section{Results}

5,7 DHT abolishes 5-HT in the rat forelimb motor neocortex and reduced TPH-positive cells in the dorsal and median raphe

There was no detectable serotonin in the motor cortex 2 weeks following 5,7 DHT-treatment $\left(\chi^{2}(1)=7.76 ; p=0.005\right)$. No significant differences were found for the amount of 5-hydroxyindoleacetic acid, norepinephrine, dopamine (DA) or 3,4-dihydroxyphenylacetic acid between 5-HT-depleted and control rats $(p>0.05$; Table 1$)$.

$\mathrm{TPH}$ immunohistochemistry revealed that the serotonin depletion caused a significant loss of TPH-positive cell bodies in the dorsal (39\%) and median (35\%) raphe compared with control rats. The total number of TPH-positive cells in the dorsal raphe was significantly lower $\left(t_{(8)}=7.41, p=0.001\right)$ in the 5-HTdepleted rats $(509 \pm 38)$ compared with the control rats $(835 \pm$ 22). The total number of TPH-positive cells in the median raphe was also significantly lower $\left(t_{(8)}=4.08, p=0.004\right)$ in the 5-HTdepleted rats $(115 \pm 7)$ compared with the control-treated rats $(176 \pm 13)$.

\section{Serotonin depletion produces higher movement thresholds and smaller motor maps in rats}

The total forelimb movement thresholds were significantly higher in nonreach-trained 5-HT-depleted $(37.37 \pm 1.22 \mu \mathrm{A})$ rats compared with control nonreach-trained $(28.60 \pm 1.24 \mu \mathrm{A})$ rats $\left(t_{(13)}=5.01, p=0.001\right.$; Fig. 1$)$. There were no significant differences in total forelimb movement thresholds between control and reach-trained $(30.40 \pm 1.52 \mu \mathrm{A})$ and 5-HT-depleted and reach-trained $(31.38 \pm 1.25 \mu \mathrm{A})$ rats. There were main effects of serotonin depletion $\left(F_{(1,35)}=27.75, p<0.001\right)$ and reach train$\operatorname{ing}\left(F_{(1,35)}=51.31, p<0.001\right)$; however, there was no significant interaction between serotonin depletion and reach training $\left(F_{(1,35)}=0.01, p=0.92\right)$. An analysis of the main effects showed that reach training significantly increased motor map size in control rats $\left(F_{(1,35)}=8.42, p=0.006\right)$ as well as in 5-HT-depleted rats $\left(F_{(1,35)}=10.05, p=0.003\right)$. No significant differences were found in the amount of ketamine $\left(F_{(3,35)}=0.55, p=0.65\right)$ or xylazine $\left(F_{(3,35)}=1.98, p=0.14\right)$ as a function of body weight and duration of surgery between groups, indicating that changes in movement thresholds and map size were not a function of anesthesia depth.

\section{Serotonin depletion results in behavioral impairments in skilled reaching}

Both the 5-HT-depleted and control rats showed a significant increase in reach attempts over the 10 training days $\left(F_{(9,110)}=\right.$

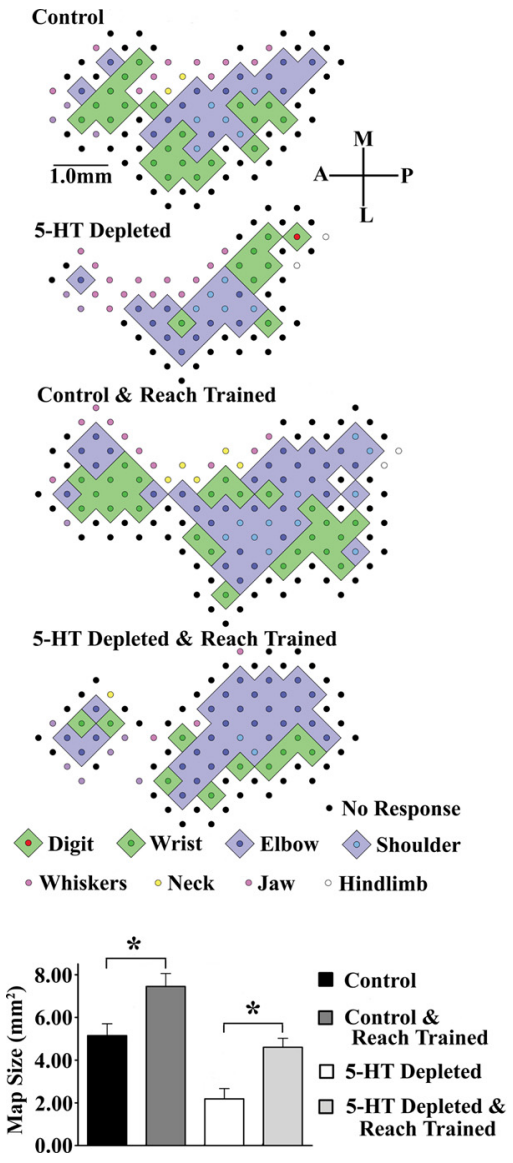

Figure 1. Serotonin depletion decreases and reach training increases motor maps. Coded forelimb movement representations of the left motor cortex of control, control and reachtrained, 5-HT-depleted, and 5-HT-depleted and reach-trained rats derived with ICMS. Map borders are defined as electrode penetration sites where a maximum current of $60 \mu \mathrm{A}$ did not elicit forelimb movements. Quantification of ICMS derived total motor map size from control, control and reach-trained, 5-HT-depleted, and 5-HT-depleted and reach-trained rats. Reach training in 5-HT-depleted rats returned maps size to control (nonreach-trained) levels. Significance was indicated when ${ }^{*} p<0.05$. Error bars indicate SEM. A, anterior; $M$, medial; $P$, posterior; $L$, lateral.

15.22, $p=0.0001)$ and while there were significant differences between 5-HT-depleted and control rats $\left(F_{(1,9)}=10.84, p=\right.$ $0.001)$, post hoc follow-up tests revealed that the 5-HT-depleted rats only had fewer reach attempts on the first $3 \mathrm{~d}$ of training. The interaction between day and group was not significant $\left(F_{(9,110)}=\right.$ $0.47, p=0.89$ ). With respect to the percentage reaching success, again both groups showed a significant increase over the 10 training days $\left(F_{(9,110)}=4.45, p=0.0001\right)$ but the 5-HT-depleted and control rats did not significantly differ in their percentage success $\left(F_{(1,9)}=2.46, p=0.37\right)$. However, a frame-by-frame analysis of forelimb movements revealed that 5-HT-depleted rats had significantly greater error scores on 3 of the 10 reaching components relative to controls. In 5-HT-depleted rats, the mean error score for component 3 , elbow to midline $(0.23 \pm 0.10)$; component 8 , supination I ( $0.18 \pm 0.07)$; and component 9 , supination II $(0.37 \pm 0.14)$ were significantly higher compared with control rats' mean error scores for components $3(0.03 \pm 0.03), 8(0.00 \pm$ $0.00)$, and $9(0.03 \pm 0.03)(z=-2.22, p=0.023 ; z=-2.40, p=$ $0.030 ; z=-2.26, p=0.023$, respectively). In control rats, component 3 , elbow to midline, is performed by the elbow being adducted to the midline while the tips of the digits retain their alignment with the midline of the body. In 5-HT-depleted rats 
the movement was missing or the rats did not fully adduct their elbow to midline. In control rats, component 8 , supination $\mathrm{I}$, as the limb is being withdrawn, the hand supinates $90^{\circ}$; however, in 5 -HT-depleted rats this movement was missing or the rats did not supinate their hand to the full $90^{\circ}$. In control rats, component 9, supination II, once the hand is withdrawn from the slot and raised to the mouth, the hand further supinates by $\sim 45^{\circ}$ to place the food in the mouth. 5-HT-depleted rats also either did not make this movement or they did not fully supinate to $45^{\circ}$. These modest effects on behavior following serotonin depletion are consistent with previous observations by (Vanderwolf, 1989; Gharbawie and Whishaw, 2003). Moreover, the alterations in a few forelimb movements are also consistent with previous reports following mild lesions of the forelimb motor map area (Gharbawie et al., 2005).

\section{Spinal cord excitability at the forelimb level is not reduced following 5-HT depletion}

Since rats with serotonin depletion exhibited higher movement thresholds and smaller motor maps, we wanted to determine whether this was caused by a hypo-excitable spinal cord. 5-HTdepleted rats had significantly higher $\mathrm{H}$-reflex amplitudes compared with control rats $\left(t_{(74)}=2.31, p=0.02\right.$; Fig. $\left.2 A, B\right)$. The normalized $\mathrm{H}$-reflexes of lesioned and control rats exhibited a significant $\left(F_{(1,6)}=30.91, p<0.0001\right)$ frequency-dependent modulation. At both 1 and $2 \mathrm{~Hz}$ the normalized H-reflex of 5-HT-depleted rats was significantly larger compared with control rats $(p<0.001$, both cases); lesioned rats had H-reflex facilitation relative to control rats (Fig. $2 C$ ). Given that changes in the spinal cord were unlikely to be responsible for the motor map and skilled reaching alterations brought about by serotonin depletion, we next asked which 5-HT receptor was involved in 5-HT action in the cortex.

Activation of 5- $\mathrm{HT}_{1 \mathrm{~A}}$ receptor results in lower movement thresholds and larger motor maps in rats

Cortical application of 8-OH-DPAT significantly $(z=-2.03$, $p=0.04$ ) lowered forelimb movement thresholds (Control = $36.23 \pm 1.73 \mu \mathrm{A} ; 8-\mathrm{OH}-\mathrm{DPAT}=31.07 \pm 2.32 \mu \mathrm{A})$. No significant $(z=-0.46, p=0.65)$ differences were found between presaline movement thresholds $(32.21 \pm 1.96 \mu \mathrm{A})$ and post saline movement thresholds $(31.17 \pm 1.57 \mu \mathrm{A})$.

With respect to total forelimb map size in control rats, saline did not have a significant $\left(t_{(4)}=1.29, p=0.27\right.$ ) effect (presaline $=6.48 \pm 0.71 \mathrm{~mm}^{2}$ and post saline $\left.=6.88 \pm 0.73 \mathrm{~mm}^{2}\right)$. However, application of $8-\mathrm{OH}-\mathrm{DPAT}$ to the motor cortex produced larger forelimb motor maps (Fig. 3).

Control rats that received 8 -OH-DPAT had significantly larger total forelimb map area compared with their pre-8-OHDPAT total forelimb map area $\left(t_{(3)}=9.70, p=0.002\right)$. Similarly 8 -OH-DPAT-induced motor map changes were found in 5-HTdepleted rats. In 5-HT-depleted rats the presaline total forelimb map size $\left(4.28 \pm 0.51 \mathrm{~mm}^{2}\right)$ was also not significantly different from the post saline map size $\left(4.68 \pm 0.63 \mathrm{~mm}^{2} ; t_{(4)}=1.75 p=\right.$ $0.16)$. However, 5-HT-depleted rats that received $8-\mathrm{OH}$-DPAT had significantly larger total forelimb map area compared with their pre-8-OH-DPAT (Fig. 3) total forelimb map area $\left(t_{(2)}=\right.$ 4.85, $p=0.04)$.

No significant differences were found in the amount of ketamine $\left(t_{(15)}=0.13, p=0.90\right)$ or xylazine $\left(t_{(15)}=0.20, p=0.84\right)$ as a function of body weight and duration of surgery between rats that received saline and rats that received $8-\mathrm{OH}$-DPAT before deriving the second forelimb motor map, indicating that changes
A

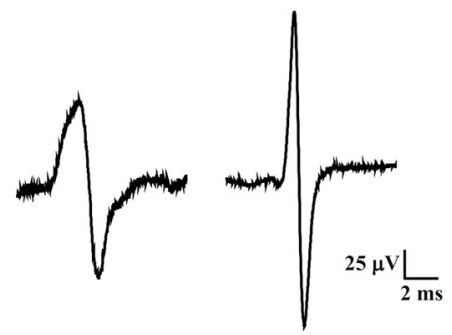

B
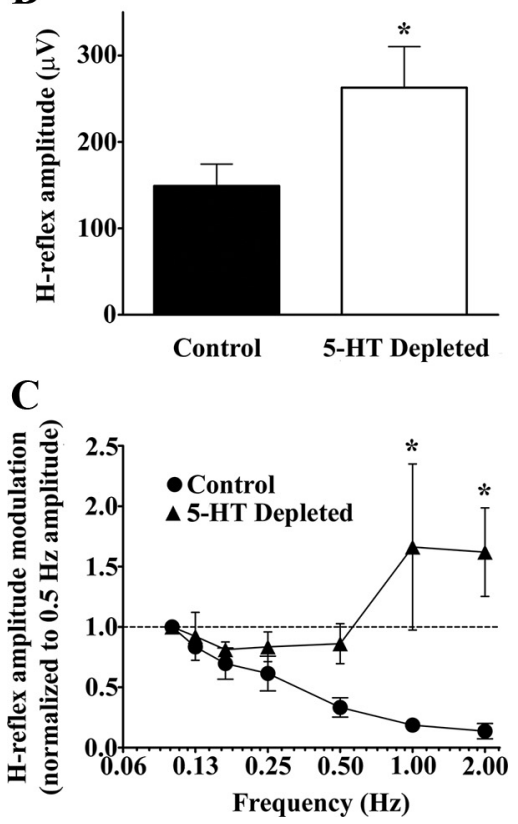

Figure 2. 5-HT depletion increased spinal reflex excitability. 5,7 DHT lesions increased $\mathrm{H}$-reflex amplitude and switched frequency-dependent depression into facilitation. $\boldsymbol{A}$, Examples of averaged (10 sweeps) H-reflex recordings from control (left) and lesioned (right) animals. Scale bar, $25 \mu \mathrm{V} / 2 \mathrm{~ms}$. B, Mean H-reflex amplitudes recorded at $0.1 \mathrm{~Hz}$, pooled from 1.0 to $2.0 \times$ threshold, was significantly larger in lesioned $(262.8+/-47.5 \mathrm{mV})$ compared with control rats $(149.2+/-25.2 \mathrm{mV}, p<0.05)$. C, The normalized H-reflexes of 5 -HT-depleted (triangles) and control rats (circles) exhibited frequency-dependent modulation. Significance was indicated when ${ }^{*} p<0.05$. Error bars indicate SEM.

in movement thresholds and map size were not a function of anesthesia depth. Overall our results indicate that serotonin increases motor map size in both control and 5-HT-depleted rats. To further explore the role of the serotonin $1 \mathrm{~A}$ receptor we mapped 5- $\mathrm{HT}_{1 \mathrm{~A}} \mathrm{KO}$ mice.

\section{$5-\mathrm{HT}_{1 \mathrm{~A}}$ receptor $\mathrm{KO}$ mice have smaller motor maps}

There was a significant effect of group on all forelimb movement thresholds $\left(F_{(2,12)}=5.35, p=0.02\right) .5-\mathrm{HT}_{1 \mathrm{~A}}$ receptor $\mathrm{KO}$ mice had significantly higher movement thresholds $(42.37 \pm 3.12 \mu \mathrm{A}$, $p=0.018)$ compared with heterozygous mice $(28.80 \pm 3.28 \mu \mathrm{A})$, but not WT mice $(34.45 \pm 2.36 \mu \mathrm{A}, p=0.18)$.

There was a significant effect of group on motor map size $\left(F_{(2,12)}=5.91, p=0.016\right) .5-\mathrm{HT}_{1 \mathrm{~A}}$ receptor $\mathrm{KO}$ mice had significantly smaller total forelimb map area $(p=0.013)$ compared with WT, but were not significantly different from heterozygous mice (Fig. 4) $(p=0.21)$.

No significant differences were found in the amount of ketamine $\left(F_{(2,12)}=0.31, p=0.74\right)$ or xylazine $\left(F_{(2,12)}=0.23, p=\right.$ $0.80)$ as a function of body weight and duration of surgery between groups, indicating that changes in movement thresholds and map size were not a function of anesthesia depth. 


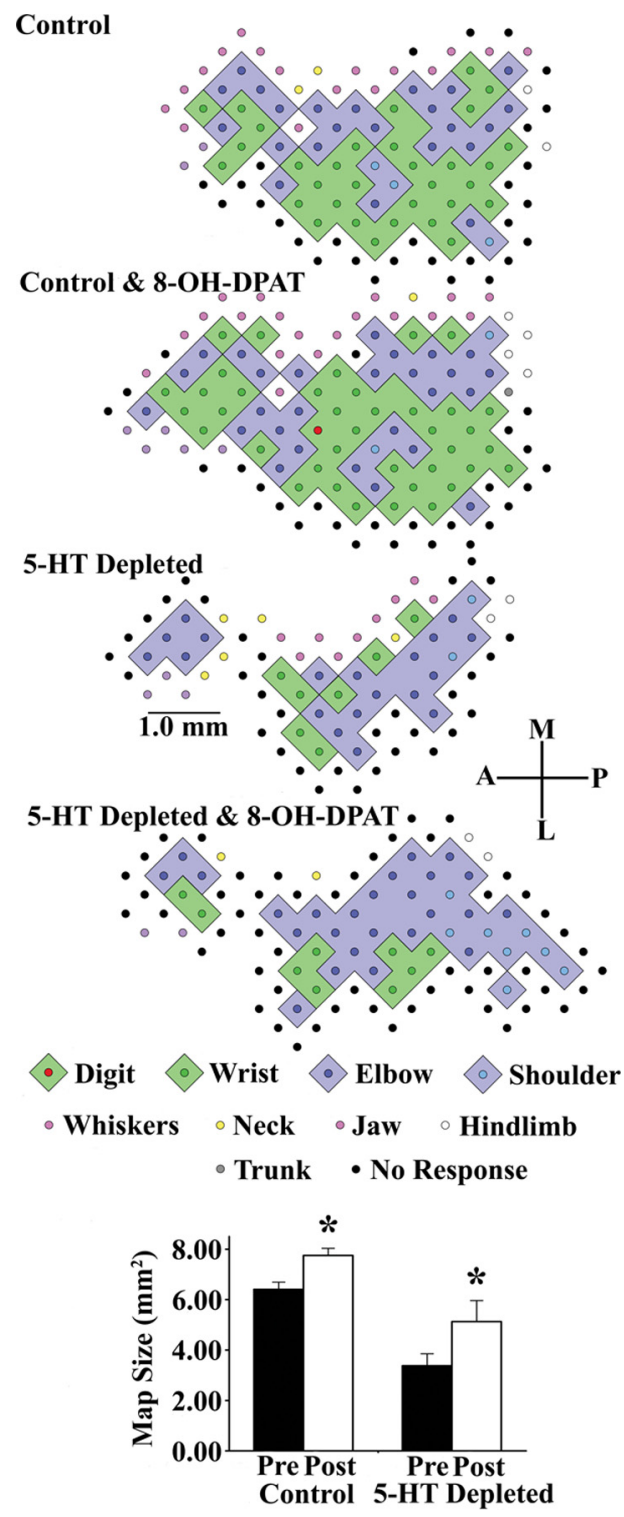

Figure 3. $5-\mathrm{HT}_{1 \mathrm{~A} / 7}$ receptor agonist (8-OH-DPAT) increases motor map size. Coded forelimb movement representations of the left motor cortex of control, control and 8-OH-DPAT, 5-HTdepleted, and 5-HT-depleted and 8-OH-DPAT rats derived with ICMS. Map borders are defined as electrode penetration sites where a maximum current of $60 \mu \mathrm{A}$ did not produce a forelimb movement. Quantification of total motor map size increased post-8-OH-DPAT in both control and 5 -HT-depleted rats. Significance was indicated when ${ }^{*} p<0.05$. Error bars indicate SEM. M, medial; P, posterior; A, anterior; L, lateral.

DRN stimulation lowers and WAY-100135 increases movement thresholds in rats

As an alternate way to elevate serotonin in the cortex we stimulated the dorsal raphe during the motor map procedure and then, to determine whether it was a serotonin-mediated effect, we blocked the raphe stimulation-induced lowering of movement thresholds with the specific serotonin $1 \mathrm{~A}$ antagonist WAY-100135.

Movement thresholds during DRN stimulation (16.85 \pm 0.91 $\mu \mathrm{A})$ were significantly lower compared with prestimulation levels $(24.74 \pm 1.21 \mu \mathrm{A} ; Z=-6.74, p=0.001)$, indicating an excitatory effect of DRN stimulation. During the poststimulation phase movement thresholds returned to prestimulation levels and were significantly higher than during DRN stimulation $(23.55 \pm 0.87 \mu \mathrm{A} ; \mathrm{Z}=6.59, p=0.001)$. This DRN stimulation
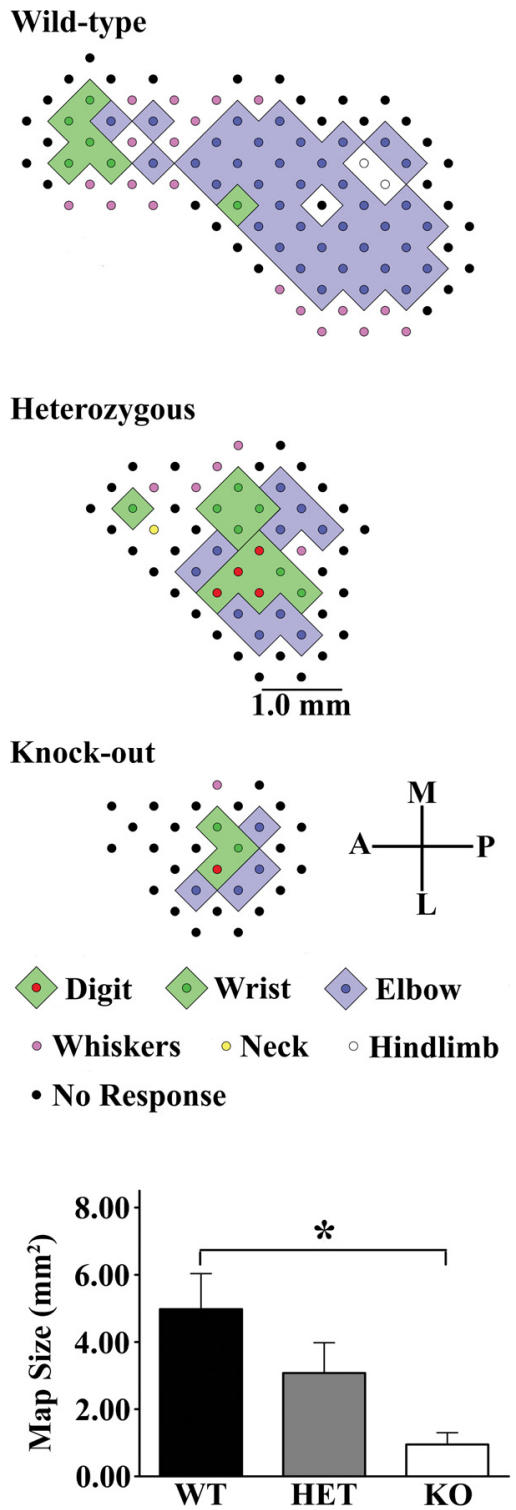

Figure 4. $\quad 5-\mathrm{HT}_{1 \mathrm{~A}}$ receptor $\mathrm{KO}$ mice have smaller motor maps. Coded forelimb movement representations of the left motor cortex of WT, heterozygous (HET), and 5-HT 1 A receptor KO mice, derived with ICMS. Map borders are defined as electrode penetration sites where a maximum current of $60 \mu \mathrm{A}$ did not produce a forelimb movement. Quantification of ICMS motor map size from WT, $\mathrm{HET}$, and $5-\mathrm{HT}_{1 \mathrm{~A}}$ receptor $\mathrm{KO}$ mice showed that $5-\mathrm{HT}_{1 \mathrm{~A}}$ receptor $\mathrm{KO}$ mice had significantly smaller total map sizes compared with WT mice. Significance was indicated when ${ }^{*} p<0.05$. Error bars indicate SEM. M, medial; P, posterior; A, anterior; L, lateral.

effect could not be accounted for by the brief 5 min interval between deriving the first, second, and third movement threshold at each penetration point as movement thresholds are stable over hours (Nudo et al., 1990).

Movement thresholds were not affected by vehicle $(0.9 \%$ saline) application to the neocortex, but WAY-100135 during DRN stimulation resulted in significantly higher movement thresholds $(21.85 \pm 1.29 \mu \mathrm{A})$ compared with stimulation alone $(16.85 \pm$ $0.91 \mu \mathrm{A} ; Z=-2.80, p=0.005)$, indicating that the movement threshold-lowering effect of DRN stimulation was mediated by 5-HT ${ }_{1 \mathrm{~A}}$ Rs.

WAY-100135 decreases ICMS-induced excitation of layer V pyramidal neurons

The in vivo ICMS motor map data thus far point to serotonin exerting an overall local excitatory effect on motor cortex via 
A

Baseline

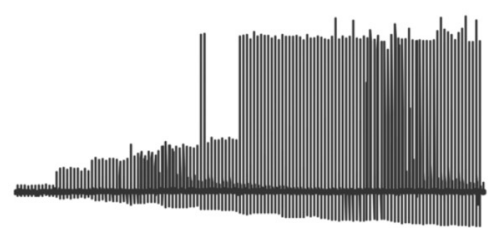

$\begin{array}{llllll}10 & 20 & 30 & 40 & 50 & 60\end{array}$ ICMS Current Intensity $(\mu \mathrm{A})$

B

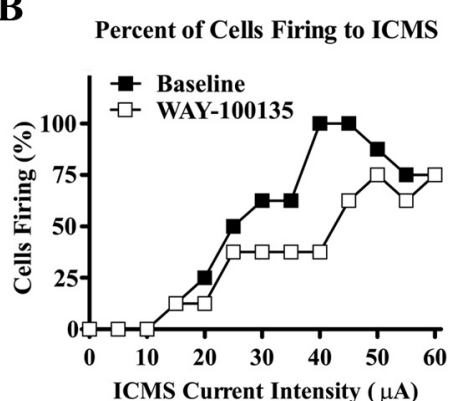

D

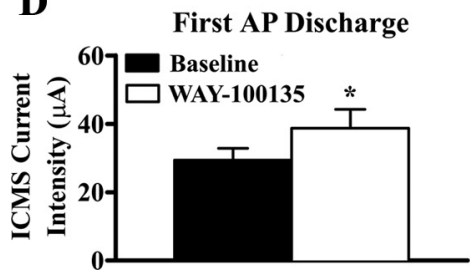

WAY-100135

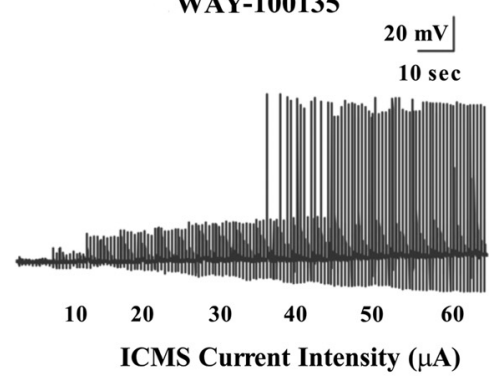

C

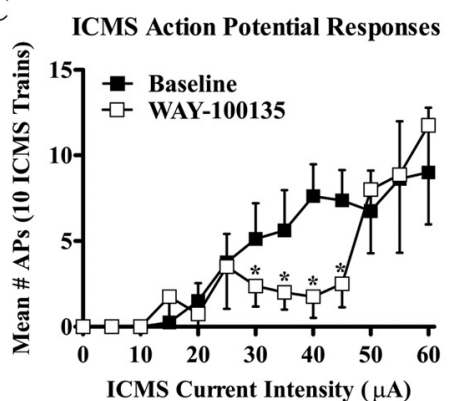

$\mathbf{E}$

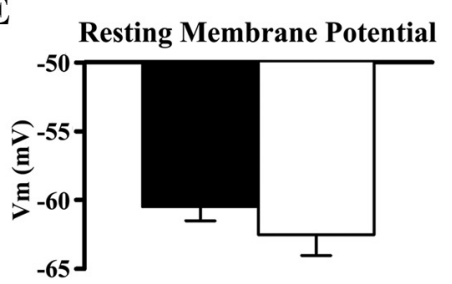

Figure 5. 5-HT 1 antagonist WAY-100135 decreases ICMS-induced excitation of layer V pyramidal neurons. In coronal slices of motor cortex ICMS stimulation was administered with an extracellular electrode (slice-ICMS) while individual layer V pyramidal neurons were recorded in a whole-cell configuration. $\boldsymbol{A}$, Two representative current-clamp traces showing the responses of a layer V pyramidal cell before (Baseline) and after (WAY-100135) bath application of WAY-100135 (10 $\mu \mathrm{M})$. ICMS current intensity was increased from 0 to $60 \mu \mathrm{A}$ in $5 \mu \mathrm{A}$ increments with $101 \mathrm{~s}$ trains at each increment (see Materials and Methods). Small vertical excursions are stimulation artifacts. $\boldsymbol{B}$, Percentage of cells firing at each $5 \mu$ A increment of ICMS stimulation. $\boldsymbol{C}$, Mean total number of APs evoked at each $5 \mu$ A increment of ICMS stimulation. $D$, The mean minimum of ICMS stimulation to first elicit an AP discharge $(n=8)$. $\boldsymbol{E}$, Mean RPM measured directly before administering ICMS stimulation to the slice. Significance was indicated when ${ }^{*} p<0.05$. Error bars indicate SEM.

$5-\mathrm{HT}_{1 \mathrm{~A}}$ Rs. To examine the possibility that serotonin is exerting this excitatory effect by contributing to the excitability of pyramidal cells from motor cortex a brain slice preparation was used. In this preparation, extracellular ICMS stimulation was applied to slices of motor cortex while whole-cell patch recordings were performed on pyramidal cells from the output layer of this brain region. Individual layer $\mathrm{V}$ pyramidal cells consistently responded to ICMS stimulation by stereotypical patterns of somatic depolarization of membrane potential and APs with increasing ICMS current intensities from 5 to $60 \mu \mathrm{A}$. Somatic depolarization occurred $<10 \mathrm{~ms}$ following the initiation of each ICMS train whereas APs were first observed with a mean latency of $19.0 \mathrm{~ms}$. Pharmacological modulation of serotonin receptors with the $5-\mathrm{HT}_{1 \mathrm{~A}}$ antagonist WAY-100135 $(10 \mu \mathrm{M})$ reduced excitation of layer V pyramidal cells in response to ICMS stimulation (Fig. $5 A$; $n=8$ cells). The number of cells responding with APs (minimum 1 AP per $5 \mu$ A increment) was reduced following WAY-100135 (Fig. $5 B)$. Cells exhibited a significantly lower number of APs following application of WAY-100135 at current increments of 30, 35, 40, and $45 \mu \mathrm{A}(p<0.05$ all cases; Fig. $5 C)$. The minimum ICMS current required to elicit the first AP was significantly increased with WAY-100135 $\left(t_{(7)}=2.14, p=0.04\right.$ Fig. $\left.5 D\right)$. There was a trend for RMP to be hyperpolarized following application of
WAY-100135 when RMP was assessed immediately before ICMS stimulation $\left(t_{(7)}=1.55, p=0.08\right.$; Fig. $\left.5 E\right)$. The input resistance of pyramidal cells was not significantly affected by WAY-100135 (PreWAY-100135: $79 \pm 8 \mathrm{M} \Omega$, Post-WAY100135: $85 \pm 7 \mathrm{M} \Omega$; $t_{(7)}=1.44, p=0.19$ ). The AP threshold of pyramidal cells was not significantly affected by WAY 100135 (Pre-WAY: $39 \pm 0.4 \mathrm{mV}$, Post-WAY: $\left.39 \pm 0.8 \mathrm{mV} ; t_{(7)}=0.83, p=0.43\right)$.

\section{8-OH-DPAT increases ICMS-induced} excitation of layer $\mathrm{V}$ pyramidal neurons Application of the $5-\mathrm{HT}_{1 \mathrm{~A} / 7}$ agonist 8-OH-DPAT $(10 \mu \mathrm{M})$ increased excitation of layer $\mathrm{V}$ pyramidal cells in response to ICMS stimulation (Fig. $6 A ; n=9$ cells). The number of cells responding with APs (minimum 1 per $5 \mu \mathrm{A}$ increment) was increased following 8-OH-DPAT (Fig. 6B). Cells exhibited a significantly higher number of APs following application of 8-OH-DPAT at ICMS current increments of 20,25 , and $30 \mu \mathrm{A}(p<0.05$ all cases; Fig. $6 C$ ). The minimum $5 \mu \mathrm{A}$ increment of ICMS current required to elicit the first AP was significantly decreased with 8-OH-DPAT $\left(t_{(8)}=8.00, p=0.0001\right.$ Fig. $6 D)$. RMP assessed immediately before ICMS stimulation was significantly depolarized following application of $8-\mathrm{OH}-$ $\operatorname{DPAT}\left(t_{(8)}=1.84, p=0.05\right.$; Fig. $\left.6 E\right)$. The input resistance of pyramidal cells was not significantly affected by $8-\mathrm{OH}-\mathrm{DPAT}$ (Pre-OH-DPAT: $90 \pm 8 \mathrm{M} \Omega$, Post-OHDPAT: $\left.87 \pm 6 \mathrm{M} \Omega ; t_{(7)}=0.64, p=0.54\right)$. The AP threshold of pyramidal cells was not significantly affected by 8-OH-DPAT (Pre-OH-DPAT: $38 \pm 1 \mathrm{mV}$, Post-OHDPAT: $\left.39 \pm 1 \mathrm{mV} ; t_{(7)}=1.03, p=0.34\right)$.

\section{Discussion}

This study is the first demonstration of a role for serotonin in the expression of motor maps. In rats, 5,7 DHT treatment that resulted in undetectable levels of serotonin in the motor cortex raised ICMS movement thresholds and decreased motor map size relative to appropriate controls. 5-HT-depleted rats also displayed errors in forelimb movements during skilled reaching. Subsequent experiments here indicate that $5-\mathrm{HT}_{1 \mathrm{~A}} \mathrm{Rs}$ contribute to serotonin's effect on motor maps by demonstrating directional excitability changes during genetic or pharmacological manipulation of these receptors.

$5-\mathrm{HT}_{1 \mathrm{~A}} \mathrm{R}$ KO mice had smaller motor map areas compared with WT controls. Direct application of the $5-\mathrm{HT}_{1 \mathrm{~A} / 7}$ agonist 8-OH-DPAT to motor cortex increased motor map expression in both naive rats and 5-HT-depleted rats. In naive rats, stimulation of the DRNs lowered ICMS movement thresholds, and this effect was blocked by the $5-\mathrm{HT}_{1 \mathrm{~A}} \mathrm{R}$ antagonist WAY-100135. Based on these in vivo data, a slice preparation was developed to examine how manipulation of 5- $\mathrm{HT}_{1 \mathrm{~A}} \mathrm{R}$ activity during ICMS stimulation affected the excitability of layer $\mathrm{V}$ pyramidal neurons that make up the principle output layer of sensorimotor cortex. ICMS stim- 
ulation delivered extracellularly to slices of motor cortex resulted in membrane depolarization of layer $\mathrm{V}$ pyramidal cells followed by AP firing as stimulation intensities were increased. The ICMS elicited AP responses were decreased with WAY-100135 and increased with 8-OHDPAT. Collectively, these data suggest that 5-HT, acting through $5 \mathrm{HT}_{1 \mathrm{~A}} \mathrm{Rs}$, has an overall excitatory effect on the neural networks that give rise to movement representations.

5-HT-depleted rats showed increased errors on three subcomponents of forelimb movements during skilled reaching behavior. While the relationship between cortical movement representations and behavior is not simple (Boychuk et al., 2011), decreases or increases in motor map size are often accompanied by deficits in fine motor control. Abnormal motor maps and decreased skilled reaching performance have previously been observed following cortical ischemia (Kleim et al., 2003), repeated seizures (Henry et al., 2008), DA depletion (Brown et al., 2011), and high-frequency stimulation intended to saturate cortical excitability (Henderson et al., 2012). While the 5-HTdepleted rats were able to learn the skilled motor task, the way in which they performed the task was altered. Together, these findings suggest that perturbations in motor maps reflect abnormalities in cortical function that contribute to behavioral deficits. It is possible that some of serotonin's contribution to motor map expression in vivo is mediated indirectly by its effect on levels of other neurotransmitters in the brain. For example, previous research has shown that serotonin affects the release of DA as well as acetylcholine (Nakai et al., 1998; Fink and Göthert, 2007); it is therefore possible that serotonin in vivo modulates available DA and acetylcholine in subcortical structures and that this could contribute to the motor map changes we observed. The changes in motor maps and behavior with serotonin depletion in this study may also in part be mediated by structures downstream of cortex, as previous studies have shown that the basal ganglia, brainstem, and cerebellum are also used in skilled motor learning and task performance (Whishaw et al., 1992, 1993, 2007). In particular, serotonin depletion may also alter spinal cord circuits that rely on serotonin. Serotonin receptors are found in the spinal cord ( $\mathrm{Da}-$ val et al., 1987; Croul et al., 1998) and serotonin modulates spinal cord reflex circuitry (Jackson and White, 1990; Elliott and Wallis, 1992; White et al., 1996; Hedo et al., 2002; Honda et al., 2004). To examine this possibility, the H-reflex was measured in 5-HTdepleted rats to assess the monosynaptic activation of $\alpha$ motor neurons by group la afferents (Ho and Waite, 2002; Hosoido et al., 2009). We observed greater H-reflex amplitudes at the level of the forelimb in 5-HT-depleted rats compared with controls. Moreover serotonin depletion caused the spinal cord to exhibit frequency-dependent facilitation, instead of depression, indicating that serotonin depletion has an effect at the level of the spinal cord.
Baseline

8-OH-DPAT

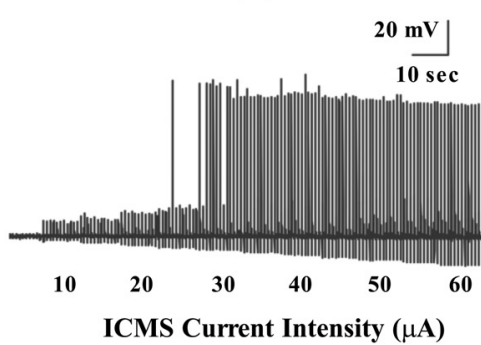

C

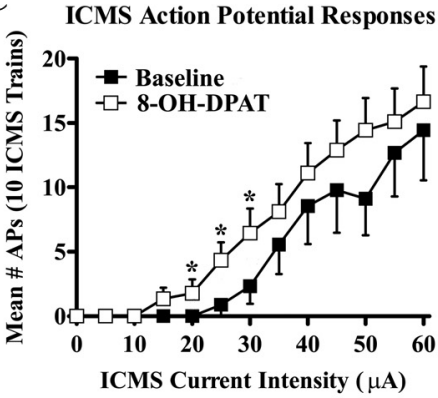

$\mathbf{E}$

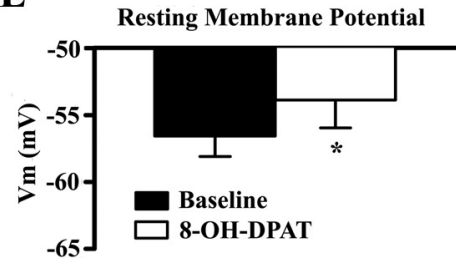

Figure 6. 5- $\mathrm{HT}_{1 \mathrm{~A} / 7}$ agonist 8-OH-DPAT increases ICMS-induced excitation of layer $\mathrm{V}$ pyramidal neurons. In coronal slices of motor cortex ICMS stimulation was administered with an extracellular electrode (slice-ICMS) while individual layer V pyramidal neurons were recorded in a whole-cell configuration. $A$, Two representative current-clamp traces showing the responses of a layer

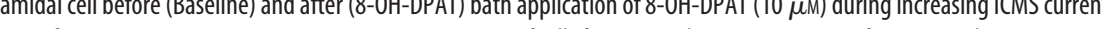
an AP discharge $(n=9)$. $E$, Mean resting membrane potential measured directly before administering ICMS stimulation to the slice. Significance was indicated when ${ }^{*} p<0.05$. Error bars indicate SEM.

One possibility for this change in the H-reflex is an increase in sensory transmission via removal of inhibition of the reflex, while another is an increase in motor neuron excitability as serotonin depletion has previously been associated with decreased motor neuron excitability (Pflieger et al., 2002). These findings suggest that the raised ICMS thresholds and decreased motor map size cannot be accounted for simply by a loss of excitability of spinal circuits following serotonin depletion.

The present results suggest that serotonin exerts an overall direct excitatory effect on cortical motor maps that is mediated by the activity of $5-\mathrm{HT}_{1 \mathrm{~A}}$ Rs. Here, cortical application of $8-\mathrm{OH}$ DPAT in vivo increased motor map size and decreased ICMS thresholds to evoke movement, whereas application of WAY100135 increased thresholds. Motor maps of $5-\mathrm{HT}_{1 \mathrm{~A}} \mathrm{R} \mathrm{KO}$ mice were smaller than WT controls. While developmental compensation is always a concern with $\mathrm{KO}$ animal models, this is likely a limited concern in the present study due to the concordance between the $\mathrm{KO}$ and antagonist findings. To further explore 5-HT-dependent changes of excitability in motor cortex, this study then used brain slices from the motor cortex to record from individual layer $\mathrm{V}$ pyramidal cells during ICMS stimulation. Moreover anesthetics are not used in the slice-ICMS preparation and therefore their potential confounding influence is removed. Since initial brain mapping studies over a century ago (Fritsch 
and Hitzig, 1870), work has centered on understanding how these motor maps relate to cortical circuitry and excitability (Graziano et al., 2002; Strick, 2002; Rathelot and Strick, 2006). Based on in vivo measurements of axon volley latencies, ICMS techniques that produce motor maps rely on direct and indirect (trans-synaptic) activation of pyramidal cells (Jankowska et al., 1975; Bolay and Dalkara, 1998). While our understanding of the brain activation responses to cortical microstimulation continues to grow, how many of the neurotransmitter systems affect motor maps is still unknown. Here, somatic whole-cell patch recordings during ICMS stimulation revealed a small set of consistent activation responses in these cells. These responses occurred in close temporal relation to the electrical ICMS train and included membrane depolarization beginning $<10 \mathrm{~ms}$ from the start of the stimulation and AP firing with increasing stimulation intensities (mean latency to fire at threshold: $19.0 \mathrm{~ms}$ ). Importantly, these slice-ICMS AP responses appear relevant to motor maps as both the in vitro and in vivo responses exhibited heightened excitability with a $5-\mathrm{HT}_{1 \mathrm{~A}} \mathrm{R}$ agonist and reduced excitability with a $5-\mathrm{HT}_{1 \mathrm{~A}} \mathrm{R}$ antagonist. In the slice-ICMS preparation WAY100135 decreased both the number of pyramidal cells firing APs and the total number of AP responses while increasing the stimulation intensities required to first elicit APs. Application of 8-OH-DPAT resulted in the opposite effect on these measures indicating that pyramidal cell excitability increased with $8-\mathrm{OH}-$ DPAT. The striking similarity between movement thresholds and slice-ICMS AP responses during pharmacological manipulation of 5-HT ${ }_{1 \mathrm{~A}}$ Rs supports that in vivo motor maps are heavily influenced by the excitability of layer $\mathrm{V}$ pyramidal cells.

Serotonin's overall excitatory effect on cortex involves a positive shift in the proportion of glutamatergic to GABAergic signaling onto pyramidal cell networks in cortex. Bath application of 5-HT increases the excitatory drive onto layer V pyramidal cells in frontal cortex by increasing frequency and amplitude of sEPSCs (Lambe et al., 2000). Fast spiking GABAergic interneurons have been shown to be involved in feedforward inhibition of pyramidal neurons (Povysheva et al., 2006). Application of serotonin reduces the activity of GABAergic neurons (Puig et al., 2010) and reduces GABA release (Kruglikov and Bernardo, 2008). A recent study has extended these findings by proposing that the preferential activation of $5-\mathrm{HT}_{1 \mathrm{~A}} \mathrm{Rs}$ on GABA cells results in disinhibition of pyramidal cells in cortex. Lladó-Pelfort et al. (2012) found that 8-OH-DPAT given intravenously reduced the discharge rate of $\mathrm{mPFC}$ fast-spiking GABAergic interneurons. This finding was partnered with the observation that administering 8-OH-DPAT intravenously produced an increase in the single unit firing rate of medial prefrontal cortex pyramidal neurons which could be reversed by WAY-100635 (Lladó-Pelfort et al., 2012). Studies using 8-OH-DPAT are cautioned because this drug possesses agonist activity for $5-\mathrm{HT}_{1 \mathrm{~A}} \mathrm{Rs}$ and $5-\mathrm{HT}_{7} \mathrm{Rs}$. In cortex, $5-\mathrm{HT}_{7} \mathrm{Rs}$ are present at low levels making it possible that they make some small contribution to the excitability changes observed with 8-OH-DPAT (Ruat et al., 1993; Hedlund and Sutcliffe, 2004). Together, studies from the literature indicate that activity of $5-\mathrm{HT}_{1 \mathrm{~A}} \mathrm{Rs}$ either promote glutamatergic or reduce GABAergic transmission onto pyramidal cells in cortex.

This is the first study to investigate the role of serotonin on the expression of motor maps. We have shown that serotonin depletion diminishes normal motor map expression and results in forelimb movement deficits during skilled reaching. Based on sensitivity to WAY-100135 and 8-OH-DPAT, serotonin appears to exert an overall excitatory effect on motor cortex through $5-\mathrm{HT}_{1 \mathrm{~A}}$ Rs. This work raises the possibility that cortical excitabil- ity may be altered in individuals with serotonin disorders or those receiving drug therapies that alter serotonin. $5-\mathrm{HT}_{1 \mathrm{~A}} \mathrm{Rs}$ represent another therapeutic target for new treatments aimed at restoring cortical excitability in injury and disease states.

\section{References}

Bandrowski AE, Huguenard JR, Prince DA (2003) Baseline glutamate levels affect group I and II mGluRs in layer $\mathrm{V}$ pyramidal neurons of rat sensorimotor cortex. J Neurophysiol 89:1308-1316. Medline

Barnes NM, Sharp T (1999) A review of central 5-HT receptors and their function. Neuropharmacology 38:1083-1152. CrossRef Medline

Bolay H, Dalkara T (1998) Mechanisms of motor dysfunction after transient MCA occlusion: persistent transmission failure in cortical synapses is a major determinant. Stroke 29:1988-1993; discussion 1994. CrossRef Medline

Bowker RM, Westlund KN, Sullivan MC, Wilber JF, Coulter JD (1983) Descending serotonergic, peptidergic and cholinergic pathways from the raphe nuclei: a multiple transmitter complex. Brain Res 288:33-48. CrossRef Medline

Boychuk JA, Adkins DL, Kleim JA (2011) Distributed versus focal cortical stimulation to enhance motor function and motor map plasticity in a rodent model of ischemia. Neurorehabil Neural Repair 25:88-97. CrossRef Medline

Brill J, Huguenard JR (2010) Enhanced infragranular and supragranular synaptic input onto layer 5 pyramidal neurons in a rat model of cortical dysplasia. Cereb Cortex 20:2926-2938. CrossRef Medline

Brown AR, Hu B, Antle MC, Teskey GC (2009) Neocortical movement representations are reduced and reorganized following bilateral intrastriatal 6-hydroxydopamine infusion and dopamine type-2 receptor antagonism. Exp Neurol 220:162-170. CrossRef Medline

Brown AR, Antle MC, Hu B, Teskey GC (2011) High frequency stimulation of the subthalamic nucleus acutely rescues motor deficits and neocortical movement representations following 6-hydroxydopamine administration in rats. Exp Neurol 231:82-90. CrossRef Medline

Cazalets JR, Sqalli-Houssaini Y, Clarac F (1992) Activation of the central pattern generators for locomotion by serotonin and excitatory amino acids in neonatal rat. J Physiol 455:187-204. Medline

Conner JM, Culberson A, Packowski C, Chiba AA, Tuszynski MH (2003) Lesions of the basal forebrain cholinergic system impair task acquisition and abolish cortical plasticity associated with motor skill learning. Neuron 38:819-829. CrossRef Medline

Conner JM, Kulczycki M, Tuszynski MH (2010) Unique contributions of distinct cholinergic projections to motor cortical plasticity and learning. Cereb Cortex 20:2739-2748. CrossRef Medline

Cowley KC, Schmidt BJ (1997) Regional distribution of the locomotor pattern-generating network in the neonatal rat spinal cord. J Neurophysiol 77:247-259. Medline

Croul S, Radzievsky A, Sverstiuk A, Murray M (1998) NK1, NMDA, 5HT1a, and $5 \mathrm{HT} 2$ receptor binding sites in the rat lumbar spinal cord: modulation following sciatic nerve crush. Exp Neurol 154:66-79. CrossRef Medline

Daval G, Verg é D, Basbaum AI, Bourgoin S, Hamon M (1987) Autoradiographic evidence of serotonin 1 binding sites on primary afferent fibres in the dorsal horn of the rat spinal cord. Neurosci Lett 16: 83:71-76. CrossRef

Dringenberg HC, Hargreaves EL, Baker GB, Cooley RK, Vanderwolf CH (1995) p-Chlorophenylalanine-induced serotonin depletion: reduction in exploratory locomotion but no obvious sensory-motor deficits. Behav Brain Res 68:229-237. CrossRef Medline

Elliott P, Wallis DI (1992) Serotonin and L-norepinephrine as mediators of altered excitability in neonatal rat motoneurons studied in vitro. Neuroscience 47:533-544. CrossRef Medline

Ferrier D (1873) Experimental researches in cerebral physiology and pathology. West Riding Lunatic Asylum Medical Reports 3:152-155.

Fink KB, Göthert M (2007) 5-HT receptor regulation of neurotransmitter release. Pharmacol Rev 59:360-417. CrossRef Medline

Flynn C, Young NA, Teskey GC (2010) Seizures, but not lowered seizure thresholds, results in larger neocortical motor maps and concomitant disruptions in skilled motor behaviour. Behav Brain Res 214:60-65. CrossRef Medline

Fritsch G, Hitzig E (1870) Ueber die elektrishe Erregarkeit des Qrosshirns. In: The cerebral cortex (Von BG, ed), pp 73-96. Springfield, IL: Thomas. 
Galic MA, Riazi K, Heida JG, Mouihate A, Fournier NM, Spencer SJ, Kalynchuk LE, Teskey GC, Pittman QJ (2008) Neonatal inflammation increases seizure susceptibility in adult rats. J Neurosci 28:6904-6913. CrossRef Medline

Gharbawie OA, Whishaw IQ (2003) Cholinergic and serotonergic neocortical projection lesions given singly or in combination cause only mild impairments on tests of skilled movement in rats: evaluation of a model of dementia. Brain Res 970:97-109. CrossRef Medline

Gharbawie OA, Gonzalez CL, Williams PT, Kleim JA, Whishaw IQ (2005) Middle cerebral artery (MCA) stroke produces dysfunction in adjacent motor cortex as detected by intracortical microstimulation in rats. Neuroscience 130:601-610. CrossRef Medline

Graziano MS, Taylor CS, Moore T, Cooke DF (2002) The cortical control of movement revisited. Neuron 36:349-362. CrossRef Medline

Hall FS, Devries AC, Fong GW, Huang S, Pert A (1999) Effects of 5,7dihydroxytryptamine depletion of tissue serotonin levels on extracellular serotonin in the striatum assessed with in vivo microdialysis: relationship to behavior. Synapse 33:16-25. CrossRef Medline

Hedlund PB, Sutcliffe JG (2004) Functional, molecular and pharmacological advances in 5-HT7 receptor research. Trends Pharmacol Sci 25:481486. CrossRef Medline

Hedo G, Ajubita M, Lopez-Garcia JA (2002) Role of serotonin 1A receptors on the modulation of rat spinal mono-synaptic reflexes in vitro. Neurosci Lett 334:41-44. CrossRef Medline

Henderson AK, Galic MA, Fouad K, Dyck RH, Pittman QJ, Teskey GC (2011) Larger cortical motor maps after seizures. Eur J Neurosci 34: 615-621. CrossRef Medline

Henderson AK, Pittman QJ, Teskey GC (2012) High frequency stimulation alters motor maps, impairs skilled reaching performance and is accompanied by an upregulation of specific GABA, glutamate and NMDA receptor subunits. Neuroscience 215:98-113. CrossRef Medline

Henry LC, Goertzen CD, Lee A, Teskey GC (2008) Repeated seizures lead to altered skilled behaviour and are associated with more highly efficacious excitatory synapses. Eur J Neurosci 27:2165-2176. CrossRef Medline

Hess G, Donoghue JP (1994) Long-term potentiation of horizontal connections provides a mechanism to reorganize cortical motor maps. J Neurophysiol 71:2543-2547. Medline

Ho SM, Waite PM (2002) Effects of different anesthetics on the paired-pulse depression of the H-reflex in adult rat. Exp Neurol 177:494-503. CrossRef Medline

Hochman S, Schmidt BJ (1998) Whole cell recordings of lumbar motoneurons during locomotor-like activity in the in-vitro neonatal rat spinal cord. J Neurophysiol 79:743-752. Medline

Honda M, Imaida K, Tanabe M, Ono H (2004) Endogenously released 5-hydroxytryptamine depresses the spinal monosynaptic reflex via 5-HT1D receptors. Eur J Pharmacol 503:55-61. CrossRef Medline

Horn T, Bauce L, Landgraf R, Pittman QJ (1995) Microdialysis with high $\mathrm{NaCl}$ causes central release of amino acids and dopamine. J Neurochem 64:1632-1644. Medline

Hosoido T, Motoyama S, Goto M, Mori F, Tajima T, Hirata H, Wada N (2009) Characteristics of $\mathrm{H}$ - and $\mathrm{M}$-waves recorded from rat forelimbs. Neurosci Lett 450:239-241. CrossRef Medline

Jackson DA, White SR (1990) Receptor subtypes mediating facilitation by serotonin of excitability of spinal motoneurons. Neuropharmacology 29: 787-797. CrossRef Medline

Jankowska E, Padel Y, Tanaka R (1975) The mode of activation of pyramidal tract cells by intracortical stimuli. J Physiol 249:617-636. Medline

Kleim JA, Barbay S, Nudo RJ (1998) Functional reorganization of the rat motor cortex following motor skill learning. J Neurophysiol 80:33213325. Medline

Kleim JA, Barbay S, Cooper NR, Hogg TM, Reidel CN, Remple MS, Nudo RJ (2002) Motor learning-dependent synaptogenesis is localized to functionally reorganized motor cortex. Neurobiol Learn Mem 77:63-77. CrossRef Medline

Kleim JA, Bruneau R, VandenBerg P, MacDonald E, Mulrooney R, Pocock D (2003) Motor cortex stimulation enhances motor recovery and reduces peri-infarct dysfunction following ischemic insult. Neurol Res 25:789793. CrossRef Medline

Kleim JA, Hogg TM, VandenBerg PM, Cooper NR, Bruneau R, Remple M (2004) Cortical synaptogenesis and motor map reorganization occur during late, but not early, phase of motor skill learning. J Neurosci 24: 628-633. CrossRef Medline
Kruglikov I, Rudy B (2008) Perisomatic GABA release and thalamocortical integration onto neocortical excitatory cells are regulated by neuromodulators. Neuron 58:911-924. CrossRef Medline

Lambe EK, Goldman-Rakic PS, Aghajanian GK (2000) Serotonin induces EPSCs preferentially in layer $\mathrm{V}$ pyramidal neurons of the frontal cortex in rats. Cereb Cortex 10:974-980. CrossRef Medline

Lanfumey L, Haj-Dahmane S, Hamon M (1993) Further assessment of the antagonist properties of the novel and selective 5-HT1A receptor ligands (+)-WAY 100135 and SDZ 216-525. Eur J Pharmacol 249:25-35. CrossRef Medline

Lee JK, Emch GS, Johnson CS, Wrathall JR (2005) Effect of spinal cord injury severity on alterations of the H-reflex. Exp Neurol 196:430-440. CrossRef Medline

Lladó-Pelfort L, Santana N, Ghisi V, Artigas F, Celada P (2012) 5-HT1A receptor agonists enhance pyramidal cell firing in prefrontal cortex through a preferential action on GABA interneurons. Cereb Cortex 22: 1487-1497. CrossRef Medline

Madriaga MA, McPhee LC, Chersa T, Christie KJ, Whelan PJ (2004) Modulation of locomotor activity by multiple $5-\mathrm{HT}$ and dopaminergic receptor subtypes in the neonatal mouse spinal cord. J Neurophysiol 92:1566-1576. CrossRef Medline

Metz GA, Piecharka DM, Kleim JA, Whishaw IQ (2004) Preserved ipsilateral-to-lesion motor map organization in the unilateral 6-OHDAtreated rat model of Parkinson's disease. Brain Res 1026:126-135. CrossRef Medline

Monfils MH, VandenBerg PM, Kleim JA, Teskey GC (2004) Long-term potentiation induces expanded movement representations and dendritic hypertrophy in layer $\mathrm{V}$ of rat sensorimotor cortex. Cereb Cortex 14:586-593. CrossRef Medline

Moore RY, Halaris AE, Jones BE (1978) Serotonin neurons of the midbrain raphe: ascending projections. J Comp Neurol 180:417-438. CrossRef Medline

Nakai K, Fujii T, Fujimoto K, Suzuki T, Kawashima K (1998) Effect of WAY-100135 on the hippocampal acetylcholine release potentiated by $8-\mathrm{OH}$ DPAT, a serotonin $1 \mathrm{~A}$ receptor agonist, in normal and p-chlorophenylalanine-treated rats as measured by the in vivo microdialysis. Neurosci Res 31:23-29. CrossRef Medline

Nudo RJ, Jenkins WM, Merzenich MM (1990) Repetitive microstimulation alters the cortical representation of movements in adult rats. Somatosens Mot Res 7:463-483. CrossRef Medline

Parks CL, Robinson PS, Sibille E, Shenk T, Toth M (1998) Increased anxiety of mice lacking the serotonin1A receptor. Proc Natl Acad Sci U S A 95: 10734-10739. CrossRef Medline

Pflieger JF, Clarac F, Vinay L (2002) Postural modifications and neuronal excitability changes induced by a short-term serotonin depletion during neonatal development in the rat. J Neurosci 22:5108-5117. Medline

Povysheva NV, Gonzalez-Burgos G, Zaitsev AV, Kröner S, Barrionuevo G, Lewis DA, Krimer LS (2006) Properties of excitatory synaptic responses in fast-spiking interneurons and pyramidal cells from monkey and rat prefrontal cortex. Cereb Cortex 16:541-552. Medline

Puig MV, Artigas F, Celada P (2005) Modulation of the activity of pyramidal neurons in rat prefrontal cortex by raphe stimulation in vivo: involvement of serotonin and GABA. Cereb Cortex 15:1-14. Medline

Puig MV, Watakabe A, Ushimaru M, Yamamori T, Kawaguchi Y (2010) Serotonin modulates fast-spiking interneuron and synchronous activity in the rat prefrontal cortex through 5-HT1A and 5-HT2A receptors. J Neurosci 30:2211-2222. CrossRef Medline

Ramanathan D, Tuszynski MH, Conner JM (2009) The basal forebrain cholinergic system is required specifically for behaviorally mediated cortical map plasticity. J Neurosci 29:5992-6000. CrossRef Medline

Rathelot JA, Strick PL (2006) Muscle representation in the macaque motor cortex: an anatomical perspective. Proc Natl Acad Sci U S A 103:82578262. CrossRef Medline

Ruat M, Traiffort E, Leurs R, Tardivel-Lacombe J, Diaz J, Arrang JM, Schwartz JC (1993) Molecular cloning, characterization, and localization of a high-affinity serotonin receptor (5-HT7) activating cAMP formation. Proc Natl Acad Sci U S A 90:8547-8551. CrossRef Medline

Schmidt BJ, Jordan LM (2000) The role of serotonin in reflex modulation and locomotor rhythm production in the mammalian spinal cord. Brain Res Bull 53:689-710. CrossRef Medline

Smith VM, Sterniczuk R, Phillips CI, Antle MC (2008) Altered photic and 
nonphotic phase shifts in 5-HT(1A) receptor knockout mice. Neuroscience 157:513-523. CrossRef Medline

Strick PL (2002) Stimulating research on motor cortex. Nat Neurosci 5:714-715. CrossRef Medline

Tennant KA, Adkins DL, Donlan NA, Asay AL, Thomas N, Kleim JA, Jones TA (2011) The organization of the forelimb representation of the C57BL/6 mouse motor cortex as defined by intracortical microstimulation and cytoarchitecture. Cereb Cortex 21:865-876. CrossRef Medline

Teskey GC, Young NA, van Rooyen F, Larson SE, Flynn C, Monfils MH, Kleim JA, Henry LC, Goertzen CD (2007) Induction of neocortical long-term depression results in smaller movement representations, fewer excitatory perforated synapses and more inhibitory synapses. Cereb Cortex 17:434-442. Medline

Vanderwolf CH (1989) A general role for serotonin in the control of behavior: studies with intracerebral 5,7-dihydroxytryptamine. Brain Res 504: 192-198. CrossRef Medline

Whishaw IQ (2000) Loss of the innate cortical engram for action patterns used in skilled reaching and the development of behavioural compensation following motor cortex lesions in the rat. Neuropharmacology 39: 788-805. CrossRef Medline

Whishaw IQ, Pellis SM, Pellis VC (1992) A behavioural study of the contributions of cells and fibers of passage in the red nucleus of the rat to postural righting, skilled movements, and learning. Behav Brain Res 52: 29-44. CrossRef Medline

Whishaw IQ, Pellis SM, Gorny B, Kolb B, Tetzlaff W (1993) Proximal and distal impairments in rat forelimb use in reaching follow unilateral pyramidal tract lesions. Behav Brain Res 56:59-76. CrossRef Medline

Whishaw IQ, Gorny B, Foroud A, Kleim JA (2003) Long-Evans and Sprague-Dawley rats have similar skilled reaching success and limb representations in motor cortex but different movements: some cautionary insights into the selection of rat strains for neurobiological motor research. Behav Brain Res 145:221-232. CrossRef Medline

Whishaw IQ, Zeeb F, Erickson C, McDonald RJ (2007) Neurotoxic lesions of the caudate-putamen on a reaching for food task in the rat: acute sensorimotor neglect and chronic qualitative motor impairment follow lateral lesions and improved success follows lateral lesions and improved success follows medial lesions. Neuroscience 146:86-97. CrossRef Medline

White SR, Fung SJ, Jackson DA, Imel KM (1996) Serotonin, norepinephrine and associated neuropeptides: effects on somatic motor neuron excitability. Prog Brain Res 107:183-199. CrossRef Medline

Young NA, Vuong J, Flynn C, Teskey GC (2011) Optimal parameters for microstimulation derived forelimb movement thresholds and motor maps in rats and mice. J Neurosci Methods 196:60-69. CrossRef Medline 